катализаторов для реакций стимулируемых микроволновым излучением //Нефтепереработка и нефтехимия №4, 2015, С.33-37.

2. Литвишков Ю.Н., Третьяков В.Ф., Талышинский Р.М., Эфендиев М.Р., Гусейнова Э.М., Шакунова Н.В., Мурадова П.А. Синтез пористого $\mathrm{A} 1 / \mathrm{Al}_{2} \mathrm{O}_{3}$-носителя для катализаторов реакций, стимулируемых электромагитным излучением СВЧ-диапазона. //Катализ в промышленности. №1, 2012, С 69-74.

3. Литвишков Ю.Н., Третьяков В.Ф., Талышинский Р.М., Эфендиев М.Р., Гусейнова Э.М., Шакунова Н.В., Мурадова П.А. Синтез пористого A1/A $1_{2} \mathrm{O}_{3}-$-носителя для катализаторов реакций, стимулируемых электромагитным излучением СВЧ-диапазона //Нанотехнологии наука и производство, №1 (10) 2011, С 5-11.

4. Гасангулиева Н.М., Нагдалиева Ю.Р., Мамедов А.Б., Шакунова Н.В., Аскеров А.Г., Литвишков Ю.Н. Влияние химического состава и условий синтеза металлсиликатной матрицы на активность цеолитсодержащих катализаторов в процессе пиролиза бензина. //Нефтепереработка и Нефтехимия №7, 2014, С. 23-26.

5. Muradova, P.A., Talyshinsky, R.M., Mardanova, N.M., Litvishkov, Yu.N. and Godjayeva, N.S. (2003) Synthesis of the Multicomponent Catalyst for Reaction of Carbon Monoxide Oxidation: Kinetic Aspects of the Problem. Process of Petrochemistry and Oil Refining, 1, 74-87.

6. ЛитвишковЮ.Н., Мурадова П.А., Эфендиев М.Р., Дадашева Ш.А., Джафарова С.А., Кулиева Л.А. Некоторые особенности формирования активной поверхности $\mathrm{Cu}-\mathrm{Cr}$ $\mathrm{Co} / \mathrm{Al}_{2} \mathrm{O}_{3} / \mathrm{Al}$-каркасных катализаторов совместного глубокого окисления монооксида углерода с $\mathrm{H}-$ бутаном в поле СВЧ.// Химические Проблемы №2,2009 стр.290-294.

7. Витязь П. А. Функциональные материалы на основе наноструктурированных порошков гидроксида алюминия / Минск: Белорусская наука, $2010,184 \mathrm{c}$.

8. Тихов С.Ф., Зайковский В.И., Фенелонов В.Б., Потапова Ю.В., Коломийчук В.Н., Садыков B.A. Пористая металлокерамика $\mathrm{Al}_{2} \mathrm{O}_{3} / \mathrm{Al}$, полученная окислением порошкообразного алюминия в гидротермальных условиях с последующей термической дегидратацией. Кинетика и катализ. 2000г., Т. 41, № 6, стр. 916-924.

9. Андреева В.А. Основы физико-химии и технологии композитов, М.: ИРЖР, 2001, 1192 с.

10. Матвеев А.Н. Электричество и магнетизм. М.: Наука, 2005.

11. Чукин Г.Д., Селезнев Ю.Л.. Механизм терморазложения бемита и модель строения оксида алюминия. Кинетика и катализ. Т.30, вып.1, 1989. С 69-76.

12. Казанский В. Б.Современные представления о механизме гетерогенного кислотного катализа // Кинетика и катализ. 1987. Т. 28. Вып.1.

13. Крылов О.В. Гетерогенный катализ. Москва : Академкнига, 2004. 679 с.

14. Ч. Сеттерфилд. Практический курс гетерогенного катализа. Пер. с англ. - М.: Мир, 1984-520c.

15. Muradova P.A., Tretyakov V.F., Zulfugarova S.M., Talishinskiy R.M., Litvishkov Yu.N. Synthesis of $\mathrm{Zn}$-B-P/Al/ $/ \mathrm{Al}_{2} \mathrm{O}_{3}$-Acylation Catalyst Diethylamino M-Toluic Acid under Exposure to Radiation of Microwave Range. International Journal of Engineering and Applied Sciences (IJEAS) ISSN: 2394-3661, Volume-2, Issue-12, December 2015.

16. П. А. Мурадова, С. М. Зульфугарова, Н. В. Шакунова, Э. М. Гусейнова, А. И. Аскерова, Ю. Н. Литвишков. Оценка эффективности катализаторов реакции совместного глубокого окисления углеводородов и монооксида углерода, протекающей под воздействием СВЧ излучения.//ЖПХ. 2017. Т. 90. Вып. 7. С. 53-58.

\title{
A LECTURE TOGETHER AS AN INNOVATIVE METHOD IN TEACHING TOXICOLOGICAL CHEMISTRY"
}

Tulegenova G.A., master of medical sciences senior lecturer, department of pharmaceutical disciplines, Marat Ospanov West Kazakhstan Medical University

SagynbazarovaA.B. candidate of pharmaceutical sciences, head of department of pharmaceutical disciplines, Marat Ospanov West Kazakhstan Medical University

Brimzhanova A.A.

lecturer, department of pharmaceutical disciplines, Marat Ospanov West Kazakhstan Medical University DOI: 10.31618/asj.2707-9864.2020.1.42.39

"ЛЕКЦИЯ ВДВОЕМ-КАК ИННОВАЦИОННЫЙ МЕТОД В ПРЕПОДАВАНИИ ТОКСИКОЛОГИЧЕСКОЙ ХИМИИ"

Тулегенова Гульбану Аскеровна, магистр медицинских наук, стариий преподаватель кафедры фармацевтических дисциплин Западно-Казахстанский медицинский университет имени Марата Оспанова 
руководитель кафедры фармацевтических дисциилин Западно-Казахстанский медицинский университет имени Марата Оспанова

Бримжнанова Айжсан Акбергеновна, преподаватель кафедры фармацевтических дисциплин Западно-Казахстанский медицинский университет имени Марата Оспанова

Annotation. The article discusses the lecture method, together in the teaching of toxicological chemistry at the Department of Pharmaceutical Disciplines, which provides knowledge, the formation of skills and development of the students' value system, professional skills and competencies.

Аннотация. В статье рассмотрены вопросы внедрения метода лекция- вдвоем в преподавании токсикологической химии на кафедре фармацевтических дисциплин, обеспечивающего получение знаний, формирование умений и навыков и развитие системы ценностей студентов, профессиональных умений и компетенций.

Key words:a lecture in two, pharmaceutical disciplines,toxicological chemistry, innovative methods.

Ключевые слова: лекция вдвоем, фармацевтические дисциплины, токсикологическая химия, инновационные методы.

Актуальность: Современная система образования претерпевает значительные преобразования: переход от традиционных методов обучения к инновационным[1].

Учитывая мировые тенденции и новые требования к подготовке квалифицированных профессиональных медицинских и фармацевтических кадров медицинские учебные заведения стран Европы, Америки, России и Казахстана переходят от традиционного обучения к инновационному образованию, с тесным междисциплинарным взаимодействием[2].

При подготовке к учебному процессу со студентами от преподавателя требуется творческий подход и компетентность самого преподавателя. Эти изменения направлены на повышение мотивации студентов к учебе, развитие клинического мышления, умение самостоятельного поиска необходимой информации, развитие у студентов навыков научно-исследовательской работы и так далее. Все реформы, которые произошли и происходят в системе высшего медицинского образования, требования, предъявляемые к преподавателю высшей школы, направлены на подготовку компетентного специалиста.

C учетом требования практического здравоохранения произошли изменения в организации учебного процесса. На практических занятиях стали чаще применять проблемноориентированное, командно-ориентированное обучение, метод клинического случая. Инновационные методы обучения, применяемые на практических занятиях, направлены на повышение мотивации студентов к учебе, развитие клинического мышления, принятие самостоятельного решения на примере конкретных ситуации, умение работать в команде, ведение дискуссии, умение отстаивать собственную точку зрения, развитие коммуникативных навыков, умение самостоятельно проводит поиск нужной информации. [3]. На кафедре фармацевтических дисциплин внедряются инновационные методы обучения. При изложении лекционного материала раньше применяли традиционный метод, а также инновационный метод: проблемные лекции. В последние годы в связи с проведением визитинга профессоров из Польши, было решено провести лекцию с профессором Познаньского университета господином Murias Marekoм по токсикологической химии у студентов 5 курса по методу «лекция вдвоем». Предметная лекция вдвоем читается преподавателями одной учебной дисциплины, межпредметная «лекция вдвоем» проводится преподавателями двух разных дисциплин. Методика чтения подобной лекции состоит из следующих этапов подготовки: 1. выбор соответствующей темы 2. подбор двух преподавателей, совместимых как с точки зрения стиля мышления, так и способа мышления 3. разработку сценария чтения лекции (блоки содержания, распределенные по времени). Во время подготовки «лекции вдвоем» два лектора пишут согласованный сценарий, в котором отражаются проблемы по данной теме лекции, распределяется время и роль лекторов и прогнозируется восприятие данной лекции студентами Лекция вдвоем фактически представляло собой мини-игру, театр двух актеров, что создавало положительные эмоции и повышало заинтересованность студентов к учебе. При чтении лекции методом «лекция вдвоем» выступление лекторов было естественным и непринужденным. Вовремя чтение лекции преподаватели применяли импровизацию. В «лекции вдвоем» лекционный материал проблемного содержания давался студентам в живом диалогов общении двух преподавателей между собой. Во время диалога стремились к тому, чтобы диалог преподавателей между собой демонстрировал культуру совместного поиска решения проблемы, с привлечением в общение студентов, которые задавали вопросы, высказывали свою позицию, формировали свое отношение к обсуждаемому материалу лекции, выражали свои эмоции во время обсуждения на лекции. [4]. Нами была выбрана актуальная тема: "Экспертиза алькогольного опьянения. Токсикокинетика этилового спирта. «Human drug metabolism-impact on mechanisms of drug toxicity».

Заключение: Таким образом можно сделать вывод о преимуществах инновационных методов обучения, как лекция вдвоем.

Она может быть использована как способ перехода от традиционных к активным формам 
обучения. "Лекция вдвоем" по сравнению с традиционной лекцией на ту же тему:

- отличается более высокой степенью активности восприятия, мышления и вовлеченности слушателей; способствует “запуску” мыслительного процесса у слушателей; · дает возможность передать больший объем информации за счет переконструирования материала и поддержания высокого уровня внимания и интереса у слушателей;

· дает большой педагогический эффект в том случае, если содержание принципиально для данного предмета или сферы деятельности; вырабатывает альтернативность мышления, уважение к чужой точке зрения, повышает культуру ведения дискуссии за счет демонстрации подобных качеств педагогов и участия самих слушателей в ней.

\section{Список литературы:}

1. Яворская С.Д., Николаева М.Г., Болгова Т.А., Горбачева Т.И. Инновационные методы обучения студентов медицинских
вузов//Современные образования. №4-2016.

проблемы

науки

2. Байділдаева А.С., Сыдық А.Н., Махамбетова М.А., Абдримова 3.М., Сарбасова Г.С. Оқытуда жаңа инновациялық әдістер мен ақпараттық технологияларды қолдану//Вестник КазНМУ.№5, 2014.-c.20-22.

3.Каримсакова Б.К., Жумабекова Т.К. Неимитационный метод обучения- "Лекция вдвоем"./ мат Международной научнопрактической конф. "Наука вчера, сегодня, завтра". Россия, г.Новосибирск,СибАК,2016 г.с,62-66.

$$
\text { 3.Дианкина М.С. Профессионализм }
$$
преподавателя высшей медицинской школы (психолого-педагогический аспект) // Москва. 2000.

4. Ступина С.Б. Технологии интерактивного обучения в высшей школе: Учебно-методическое пособие. Саратов: Издательский центр «Наука», 2009. -52 c. 